\title{
A Review of Significant Contributions of Psychology to Canadian Higher Education*
}

\author{
JANET GAIL DONALD $\dagger$
}

\begin{abstract}
Psychological research in several areas has made or shows the potential to make significant contributions to Canadian higher education. At the most microscopic level, cognition and learning, researchers have examined factors affecting learning, how students organize course material, and how information is processed. The evaluation of learning and the measurement of student abilities in higher education have benefitted from psychological methods. Instruction is a critical process in higher education and research in that area considers the goals and competencies of instruction, the effect of different methods of instruction on learning, and the evaluation of teaching. At a more general level, research into student characteristics covers social and moral development as well as patterns of achievement. At the most global level, the organization and operation of the university, program evaluation is a prominent need and staff development is considered. Overall a review of the research suggests important factors which could affect higher education, but the need for more organized and continued study of these factors and their effects is evident. In-depth study of learning in the university, analysis of student characteristics and their effects on learning, and research on the programs and operation of the university are priorities for future research.
\end{abstract}

\section{RÉSUMÉ}

La psychologie a fait ou pourrait faire une contribution significative à l'éducation supérieure dans plusieurs domaines. Au niveau le plus microscopique, celui de la connaissance et de l'apprentissage, les chercheurs ont examiné les éléments ayant un effet sur l'apprentissage et comment les étudiants organisent leurs idées. Les méthodes psychologiques ont contribué à l'évaluation de l'apprentissage et à la mesure des capacités des étudiants. L'enseignement, processus très important dans le monde de l'éducation supérieure, mérite beaucoup de recherches, particulièrement sur les methodes de l'enseignement et son évaluation. La recherche dans le domaine des caractéristiques des étudiants concerne leur développement social et moral et leur succès à l'université. Au niveau le plus global, l'organisation et l'opération de l'université ainsi que l'évaluation des programmes sont des

* Revised version of paper presented at the Annual Meeting of the Canadian Society for the Study of Higher Education, Halifax, June 1981.

†Centre for Teaching and Learning Services McGill University. 
besoins critiques. Somme toute, la revue de la recherche suggère des éléments importants dans le domaine de l'éducation supérieure, mais le besoin d'une étude plus organisée et plus continue est évident. Les buts prioritaires de la recherche dans le futur seront l'étude de l'apprentissage dans l'universitè, l'analyse des charactéristiques des étudiants et l'étude des programmes de l'université.

\section{INTRODUCTION}

A review of the significant contributions in a field consists of two stages. In the first stage, the relevant research literature is gathered from all potential sources, sorted into meaningful categories, and described. The second stage is more difficult: a judgement of the significance in terms of the actual or potential effects of the research must be made. This leads to a revelation of the lacunae in the field of research, those things which we have not done and which ought to be done. Closure or absolution comes in the form of recommendations for future research in the area.

To determine what the relevant research is in the field, we must first look at the context of the relationship psychology has to higher education. When we study higher education, we usually study administration and finance, or history and planning, the "public life" of the institution (Trow, 1975). Much less frequently do we study the "private life" - everything related to teaching and learning - in the institution. A review of articles published in the Canadian Journal of Higher Education suggests that psychology, as represented by learning, instruction, and evaluation, represents ten percent of the total contribution to our understanding of higher education (see Figure 1).

But this is not to say that the contribution of psychology is necessarily small or that little psychological research of relevance to higher education has been accomplished. In fact, there is an abundance of psychological research available on higher education, in part because university students are a favored source of subjects for psychological research. A wealth of knowledge about university and college students exists, not only about how they learn, think, and respond to instruction, but about their sensation and perception, and about clinical, personality, and social factors. A scan of 5 years of articles in the Canadian Journal of Behavioral Science from 1975 to 1980 produced 47 articles with the university student as subject. The left-hand circle of Figure 1 shows the categories into which these articles fell, with the categories based on the dominant factors in the experiments. Although for the purposes of this review I dealt primarily with the categories of learning, instruction, and cognition, which included 19 of the 47 articles, Figure 1 suggests an as yet unutilized domain of knowledge about the students in our universities.

The major sources of research were Canadian journals in psychology, education, and higher education and known researchers in the field. To be included in the survey, the researchers had to be working in a Canadian setting, and experimental subjects had to be students at a Canadian institution of higher education. These limits were chosen because they represent the known and accessible and therefore potentially effective research available in Canadian higher education. The final selection of research included over 100 journal articles, and books and monographs published between 1970 and 1980 .

The important areas or categories of psychological contributions to Canadian higher 

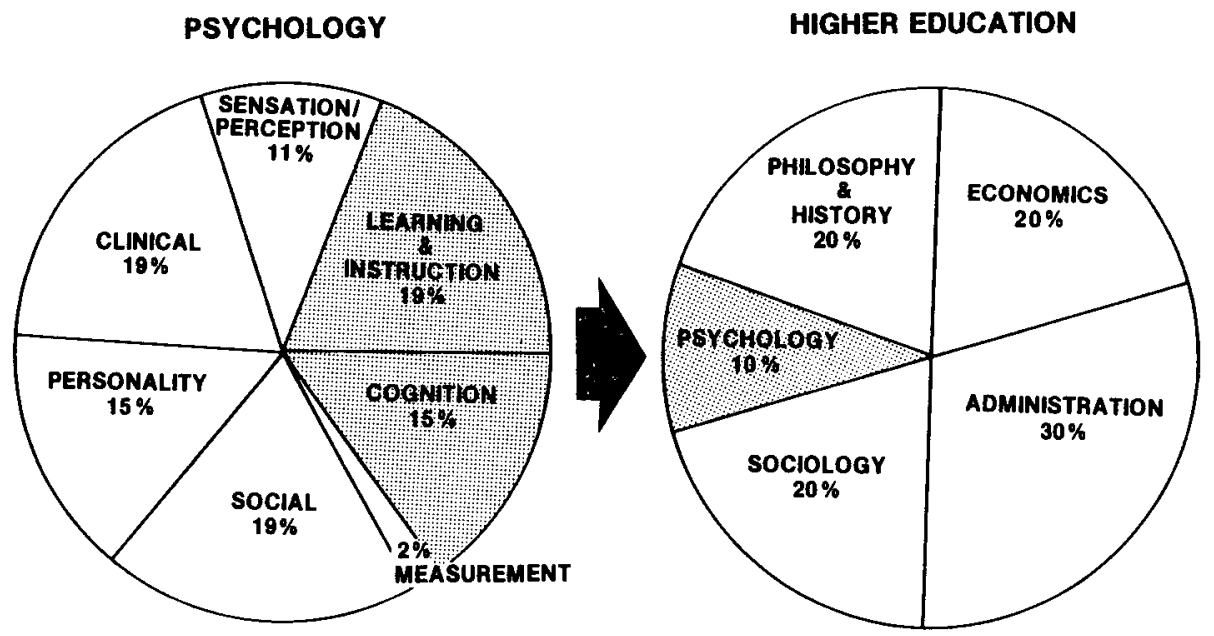

Fig 1: The contribution of psychology to Canadian Higher Education

education stand out clearly. The most potentially important area of contribution from the perspective of psychologists is learning, which is primarily cognitive or conceptual in nature in the university (see Table 1). Psychology is not only a field of knowledge with research findings on topics such as how students organize course material. It also is concerned with a set of methods or processes for operating or making decisions. Within the area of learning in the university, these methods deal principally with the evaluation of learning and the measurement of student abilities. Seen from the perspective of the university or college, instruction is the psychological contribution of paramount importance. More of the research done to date in instruction deals with methods of teaching or its evaluation, than with factors affecting instruction. At a more general level, research into student characteristics looks at their social and moral development as well as patterns of achievement. The methods in this area are concerned with selecting and upgrading students. At the most global level, the organization and operation of the university, the principal topics were staff development and the role of psychology in the university. The methods at this level focus on special programs in higher education, and evaluation in and of the university. Table 1 traces the available research findings and methods that psychology has contributed to Canadian higher education in the past decade. The table progresses from the most microscopic and perhaps most fundamental area of psychological research, cognition and learning, to the most global and perhaps most far-reaching area of contributions.

\section{COGNITION AND LEARNING}

Cognition and learning are the most fundamental processes which occur in higher education. The production and dissemination of knowledge, the basic goals of universities and colleges, occur through the processes of cognition and learning. The literature in this area deals with the factors affecting learning, how what is learned is structured or organized, and the process of thinking or learning. A considerable amount of research has been done by Canadian psychologists on the differential effects of concrete and abstract learning materials (Humphreys \& Yuille, 1973; O’Neill \& Paivio, 1978; Runquist \& Blackmore, 
1973; Yarmey \& Sayer, 1972). The research consistently supports the greater effect of concrete materials or presentation on recall. For example, Humphreys and Yuille found that concreteness increased the retrieval of nouns from memory, while in the Yarmey and Sayer experiments, concrete drawings of noun concepts done by students facilitated recall. In conjunction with the question of concrete versus abstract materials, the effect of imagery has been studied. Although noun phrase concreteness produced greater recognition and recall, verb imagery did not in a study by Yuille and Holyoak (1974). Students who were high in imagery ability produced images and words faster than those who were low in imagery ability (Ernest \& Paivio, 1971). Instructions to create a mental image of pairs of pictures or words resulted in greater recall than did instructions to repeat the stimuli (Yarmey \& Barker, 1971). This research suggests that the mode of learning materials affects learning, a finding of some import in the planning of instruction. For example, in science courses, there is a greater tendency to use concrete or imaginable concepts than in the social sciences (Donald, 1980). Learning could be facilitated by the use of concrete examples or by images.

The organization of information and the effects of a cognitive structure are also critical to understanding the process of learning in higher education. We know that a primary request students make of their professors is for analysis and synthesis of the subject matter, and what professors want of their students is that same ability to organize information in a meaningful way. One of the most important factors guiding cognitive organization is the use of similarities. In one study, students who used similarity rather than difference as a basis for understanding complex concepts perceived the attributes of the concept as being more closely related (Cochran, 1976). In another study, context was shown to have a generalizing effect on judgement rather than to cause a meaning shift (Lamarche, 1977). Context was therefore used as a basis for similarity thinking. Categorization has been shown to be influenced by a number of factors, the most important of them being the centrality of an instance, that is, the degree of semantic match between an example of concept and the concept itself (Green \& Cochran, 1978). The number of examples and the intensity or extremity of rating also influence categorization. These findings only begin to lay bare the mental operations we use when we organize information.

The effect of conceptual structure on students has also received attention. Reasoning has been found to depend upon generalization procedures, such as using a hierarchy (set-subset relations) or using induction or probability reasoning (Reich, 1974). Courses in different disciplines demand different kinds of cognitive structuring because of the kinds of relationships found between major concepts in the course (Donald, 1980). The kind of conceptual structure that a student has affects the student's willingness to expose himself or herself to discrepant information (Sandilands, 1974). Thus, not only does the research provide insight into the potential complexity of cognitive organization, but also the recognition that cognitive structure affects student learning behavior.

A particular case of cognitive organization research in Canada centers on second language learning. Bilinguals' organization patterns seem to be similar in their two languages, although language has a stronger effect than semantic category (Taylor, 1971). Students using their second language were affected by casual or formal speaking situations; familiarity with their own second language directed their ease and thus how positive their evaluation was of the person to whom they were speaking (Segalowitz, 1976). In this instance, context and cognitive structure interacted to affect evaluative behavior. 
Table 1

Areas of Psychological Contributions to Canadian Higher Education

\begin{tabular}{lll}
\hline $\begin{array}{l}\text { Cognition } \\
\text { and }\end{array}$ & $\begin{array}{l}\text { Abstraction/Concreteness/ } \\
\text { Imagery } \\
\text { Learning }\end{array}$ & $\begin{array}{l}\text { Cognitive organization } \\
\text { Cognitive operations } \\
\text { Grades } \\
\text { Abilities } \\
\text { Kinds of evaluation }\end{array}$ \\
\hline Instruction & $\begin{array}{l}\text { Goals and competencies } \\
\text { Instruction and learning }\end{array}$ & $\begin{array}{l}\text { Teaching methods } \\
\text { Evaluation of teaching }\end{array}$ \\
\hline $\begin{array}{l}\text { Student } \\
\text { Characteristics }\end{array}$ & $\begin{array}{l}\text { Social characteristics } \\
\text { Student achievement }\end{array}$ & $\begin{array}{l}\text { Selection methods } \\
\text { Upgrading programs }\end{array}$ \\
\hline $\begin{array}{l}\text { Moral development } \\
\text { Operation }\end{array}$ & $\begin{array}{l}\text { Psychological services in } \\
\text { the university }\end{array}$ & $\begin{array}{l}\text { Programs } \\
\text { Research } \\
\text { Organization }\end{array}$ \\
\hline
\end{tabular}

Cognitive operations or information processing form a third theme in the research on cognition and learning. Instead of approaching cognition in terms of semantic context or images stored in the brain, these researchers treat remembering or thinking as an operation in which memory consists of techniques for generating or recreating events instead of the objects or events themselves (Kolers, 1974). Students not only remember previously read sentences semantically, they also retain detailed information about pictorial aspects of the sentences for lengthy periods. This suggests that two kinds of processing occur when students learn. In an attempt to distinguish between two types of cognitive processing, simultaneous or holistically and spatially organized, versus successive, that is, temporally organized (rote) learning, Vernon, Ryba and Lang (1978) analyzed university students' abilities by multiple factor analysis. They found some support for rote or successive processing, but found that rather than a general simultaneous processing factor, there were several factors which described the students' abilities. The implication is that university students have a set of abilities or cognitive processes rather than one. Thus learning could be expected to depend not as much on a general factor such as intelligence, but on more specific ones such as the abilities to categorize, analyze, or think logically. 
Cognitive processes are affected by external factors as well. Hartsough (1975) found that associative but non-meaningful connections between words affected recall, which suggests that contiguity has an effect on suppositions of semantic relatedness. It would be particularly important to be aware of this tendency to err in programs where diagnostic or subjective evaluation procedures are taught. Subliminal stimuli have also been shown to have an effect on the learning of concepts when the subliminal stimuli are symbolic but not when perceptual (Leclerc \& Freibergs, 1971). Both of these studies point to the effect of interference or context on cognitive processes. Context and mode are important variables in learning and instruction, and their interaction with cognitive structure poses some interesting questions for higher education.

\section{EVALUATION OF LEARNING}

If learning is the most fundamental process in higher education, we could suppose that its evaluation would have received considerable attention. Not so. Little research has been done in this area to date, and the evaluation of learning remains a practice without benefit of theory or empirical evidence. Recent attention has been paid in many Canadian universities, however, to grading systems and their meaning. The change in the usage of grades, from a normal curve to a mastery paradigm, has resulted in the loss of the average " $C$ " and a demand for more explicit criteria of what an " $A$ " or a " $B$ " represents. There has been a move to rationalize grading systems and to make them more understandable across Canada. Since Taylor's (1977) article on different grading systems among Canadian universities, clarifications have been made to the grading systems within and across several universities. Mason (1978) suggested a method of grading which takes into account the difficulty level of a particular test so that marks can be assigned more consistently. Work on grading procedures is of major practical import in higher education: the assignment of grades is one of the most contentious issues. Within the university, however, we need greater sophistication in understanding what a grade means.

The measurement of student abilities often consists of validations of standardized tests on Canadian students. The studies provide us with normative data on the Canadian university student's abilities, frequently with a built-in comparison to the American student. The study skills of a Canadian university group have been tested in this manner (Thompson, Reberg \& Uhlemann, 1978), as has a creativity scale (Taylor \& Fish, 1979). This is an area which could provide us with a baseline for understanding the background abilities of our students, a sine qua non for determining how much has been learned and how our students develop in the university.

Factors which affect the evaluation of learning include goals, learning conditions, and different evaluation procedures. Do goals affect performance? University students responded to higher goal levels on some tasks (Bavelas \& Lee, 1978). Providing goal levels caused variations in the quality as well as the quantity or responses: there appeared to be a trade-off between quality and quantity. In a study of an undergraduate thesis research course, the clarification of goals and of the evaluation procedure produced a better approximation of the conditions under which graduate work and research are done (Furedy \& Furedy, 1978). Students were expected to work within research publication paradigm. Grades were used for each component to provide academic significance. The stimulation produced tension but placed responsibility for learning clearly on the student. Self-evaluation was more accurate where students were given specific guidelines or feedback 
on their performance (Carr, 1977). Furthermore, the guidelines improved performance. There has also been work done on validation procedures to ensure that self-evaluation has taken place according to instructions (Bellerose, Bégin, Frenette \& de Montigny, 1980). These relatively innovative approaches to evaluation offer direction for the future: they delineate criteria for success, with the understanding that evaluation procedures affect the amount and kind of learning that will take place, and they take account of the formative role of evaluation in student skill development. Among more traditional modes of evaluating learning, third and fourth year Canadian university students considered that preparation for an in-class examination or take-home examinations provided them with better learning opportunities than preparation for writing a paper, research proposal, or annotated bibliography, for presenting a seminar, or for bi-weekly quizzes or oral examinations (Foth, 1975).

The evaluation of student learning is an area where wide differences in approach occur throughout the institution. While in some corners a battle rages over the meaning of a grade, in others, making evaluation more meaningful and useful is focal. University or college policy on the evaluation of learning needs to be clarified on the basis of what is being learned and what the goals of education are.

\section{INSTRUCTION}

The most obvious and practical application of psychology to higher education is in teaching or instruction. Psychologists have, however, done relatively little work on the factors affecting instruction. Far more work has been done to delineate teaching methods and to deal with the evaluation of teaching. What research has been accomplished may be of the greatest significance to higher education.

In a survey of over one thousand Canadian university graduates from 1958, 1963, and 1968, Sheffield (1974) sought the characteristics of effective teaching by asking the graduates to comment on the characteristics, qualities, methods and procedures which identified the professors they named excellent teachers. From these an overall pattern was produced and comparisons were made between universities, disciplines, and course levels. The characteristics closely matched findings from other English-language countries and confirmed a general list of good teaching characteristics. Those most frequently mentioned were: subject mastery; well-prepared lectures; subject related to life; students' questions encouraged; and enthusiasm for subject. Teaching competencies provide a framework for considering instruction in higher education (Magsino, 1979; Morin, 1976).

A variety of factors have been shown to affect instruction and learning. Sullivan $(1974,1975)$ pointed out the importance of the characteristics of the learner, the characteristics of the subject matter, and time as variables in university teaching research. He found that these all had major effects on learning outcomes. When two kinds of instruction were used to teach problem-solving skills, it was found that the different methods, provision of rules or demonstration, had different effects on specific skills (Berg \& Stone, 1978). Students were able to profit more from being given rules than by a demonstration of problem-solving behaviors in problem definition, but the demonstration was more effective in facilitating the generation of alternatives and in choice behavior. In a study of creativity, students who were provided with a list of alternatives produced higher scores, however, a grouping of the alternatives had no effect (Riverin-Simard, 1977). The effect of instruction on cognitive structure has been studied by Traub and Hambleton 
(1974) and is the subject of my current research. Traub and Hambleton measured how closely students judged statistical course concepts to be related before and after a course. They found that instruction produced a more highly organized and smaller cognitive structure than existed beforehand. In my study of the development of students' cognitive structure, students whose cognitive structures were more consistent with the professor's also were higher achievers in the course. The important variables which affect teaching outcomes have just begun to be delineated.

\section{TEACHING METHODS}

A variety of teaching methods have been written about. Many are concerned with forms of individualized instruction and several pertain to professional training, particularly in education. How to improve lecturing is dealt with by Furedy (1979) who discusses the organizational and presentation aspects of the method as well as ways of systematically improving lectures. Within the realm of individualized instruction, audiovisual and computer assisted instruction in medicine have been compared, personalized instruction was reviewed, and a course taught by learning contract was described (Gagné, d'Ivernois, Parent \& Marquis, 1976; Castonguay-Leblanc, 1977; Demers, 1978). Goldschmid and Goldschmid (1972), Shore (1975) and Donald (1977) explored the components of individualized instruction with the aim of aiding the professor to personalize learning in the university.

Self-instruction with frequent feedback has proven successful in the practical training of teachers (Allard, 1977). The integration of theory and practice in teacher training has been discussed and methods for accomplishing this integration have been tested (Allen, 1976; Cantin \& Chené-Williams, 1978; Clifton \& Covert, 1977). In response to studies which showed a decline in self-concept due to student teaching experiences, Gregory and Allen (1978) explored the effects of a teaching practicum and found that although selfconcept declined at first, it later recovered with longer continuous teaching experience under conditions which provided a high level of support. More formal education was found to be related to student teachers having enlarged perspectives, i.e., being more broadminded (Emerson, 1977). What is of particular interest about research on the education of teachers is that the issues contended with, such as self-instruction or the integration of theory and practice, are core issues in lifelong learning which are rarely broached elsewhere in higher education.

Several divergent topics in university instruction are worthy of note. One concerns the attempt to define affective teaching objectives such as students' attitudes and values to be gained (Gingras, 1975). Fostering appreciation for a discipline or for learning in general, and nurturing the will to learn are not only philosophically sound goals but necessary strategies for our students to benefit from higher education. Another topic concerns the psychology of teaching in a particular discipline, music (Pedersen, 1977). A third poses the dilemma of Canadian content in the culturally sensitive area of social psychology (Sadava, 1978). Each of these articles provides insight on less central but still salient factors to be considered in higher education instruction.

A series of articles has centered on the training of teaching assistants in Canadian universities. A survey of teaching assistant programs across Canada shows a variety of methods being used (Marx, Ellis \& Martin, 1979). A training program based on the components of effective teaching resulted in better teaching attitudes and better student atti- 
tudes, perceptions, and achievement (Martin, Marx, Hasell \& Ellis, 1978; Marx, Martin, Ellis \& Hasel, 1978). The move to economize in higher education may make programs like this of high practical significance since teaching assistants may increasingly be called upon to aid overburdened faculty.

\section{EVALUATION OF TEACHING}

This area of research has received more attention than any other in psychology applied to higher education. The book, If Teaching is important. . the evaluation of instruction in higher education (Knapper et al., 1977), published for the Canadian Association of University Teachers, covers teaching evaluation from definition to the design of student rating questionnaires. Components of the evaluation of teaching, including student learning, self-assessment and administrative evaluation, as well as discussions of university goals and academic functions, provide a framework for viewing the evaluation of teaching. $\mathrm{A}$ particularly useful chapter for the university professor or department contemplating teaching evaluation is that of Nadeau, who reviews the variables affecting the validity of student ratings. An issue of the Canadian Journal of Higher Education is devoted more to methods of evaluation although two articles by Geis (1979) and Pascal and Davey (1979) deal with the purpose and politics of evaluation. Parent (1979) discusses the role of a university pedagogical service in course evaluation, Cranton (1979) describes the system developed at McGill University, and Dowdeswell and Good (1979) portray a case study of a departmental evaluation. The journal also includes a bibliography of the evaluation of instruction (Davey, 1979).

The research on the evaluation of teaching considers both the context of evaluation (Leibu, 1976) and different measurement techniques (Das, Frost \& Barnowe, 1979; Leventhal, 1975). A series of publications by Leventhal, Perry and Abrami deal with factors affecting student ratings, and Murray (1979) has reviewed the research in this area, a considerable portion of which he is responsible for. In a review of research on college teaching, Knapper (1980) draws attention to the wide body of research on student ratings done in Canada. This covers work on the reliability of teacher rating forms and their validity, comparisons of ratings by students and peers, the relation of ratings to measures of learning, and factors affecting the validity of ratings such as student expectations and the instructor's teaching reputation. The principal findings are that different ratings on the same professor are highly correlated whether different forms are used or ratings are taken at different times of the year or over successive years (Murray, 1972). The correlation between student and peer evaluations is less clear as it is between ratings and course achievement. Students who choose their instructor on the basis of teaching reputation rate the instructor higher (Leventhal, Abrami \& Perry, 1976).

Adjunct to the teaching evaluation process is work associated with the improvement of teaching. Studies by Donald (1978) and by Foster and Nelson (1980) point to the felt need among university professors to improve their instructional procedures and the evaluation of student learning. The variety of approaches to instructional improvement across Canada were documented by Donald and Shore (1976) in the Annotated index to pedagogical services in Canadian colleges and universities. These approaches include evaluation and course improvement consultations, workshops, publications, and further research in the area. The methods given highest priority in the Foster and Nelson survey were workshops on teaching techniques with outside consultants and speakers, and the provision of more team teaching opportunities. 


\section{STUDENT CHARACTERISTICS}

As mentioned at the beginning of this article, an abundance of research on university students exists; but much of it does not deal with the student in the context of higher education. Indeed, the lack of systematic study is striking and one is prompted to ask, "if so much of student success is held to depend upon the students themselves, how is it that we know so little about them?"

The research findings provide hints about the social and personality characteristics of university students, student achievement, and moral development. The social and personality characteristics studied have included national identity, student drug use, the effect of physical attractiveness on expectations, the meaning of pornographic stimuli, and sexism in the university: a hodgepoge of personal attributes, but interesting for the directions they suggest for understanding the student population. Canadian students at the University of Saskatchewan identified strongly both with the country as a whole and with the Prairies (Morse, 1977). Contact with foreigners, travel within Canada, and exposure to Canadian symbols made them more conscious of being Canadians. Student drug use, a topic of high salience during the early seventies, was found to be associated with lower expectations of academic recognition (Sadava, 1971). Drug users showed higher expectations for personal independence, more positive attitudes toward drug use, greater tolerance of use and greater social support for use (Sadava, 1973). Student teachers rated their pupils as more able if they were physically attractive (Clifton \& Baksh, 1978). Students applying for graduate studies in psychology did not appear to receive recommendations which were sex-biased (Henderson, Briere \& Hartsough, 1980). College males rated pomographic materials negatively, that is, as bad, unpleasant, and harmful, but also as active, hot, and stimulating (Ware, Brown, Amoroso, Pilkey \& Pruesse, 1972). This scattered set of findings about student characteristics suggests that although students have been the subjects for much experimentation in psychology, the office of the Dean of Students would have difficulty in utilizing it.

Student achievement has received no more comprehensive study. Learned helplessness, in which students become apathetic or less able because they fail to achieve after working hard, has been investigated by Perry, Leventhal, Abrami and Deekins (1978) and by Sergent and Lambert (1979). Although Perry et al. did not get conclusive findings, Sergent and Lambert found that uncontrollability of the situation was not a necessary or sufficient condition for producing helplessness but that failure or learned incompetence is a better way of describing the phenomenon. Students who were more depressed tended to attribute failure to more personal, stable, and global causes, and where failure was attributed to the lack of an important ability, the greater was the depressive effect following failure (Zemore \& Johansen, 1980).

The development of moral behavior and judgment has been the focus of several researchers. Although cognitive factors have been demonstrated to parallel moral thinking, Percival (1979) questioned if different forms of motivation or incentives would also affect behavior. University students at different levels of moral development responded to the predicted incentives for task performance. The results suggest giving greater attention to motivational factors when moral development is investigated. In a study of the relationship between levels of moral judgment maturity and locus of control, it was found that advanced moral reasoning was related to the perception of having control over matters (Connolly \& McCarrey, 1978). Male students tended to perceive themselves as having more control socio-politically, while female students tended to perceive themselves as 
having more control globally. When students were given information about research into bystander helping in emergency situations, they responded faster to an actual emergency situation (Rayko, 1977). Students who were alone were faster and more likely to intervene than students in the company of a non-responding companion. Students' moral reasoning was also found to be related to the tendency to support student activism in the university (Quarter, 1974). Students with principled (advanced) reasoning were more likely to be anti-authoritarian and students with conventional moral reasoning were more likely to react against the student movement. These studies suggest that different incentives, knowledge, and a sense of control affect students' moral behavior, and that student activism and advanced moral reasoning are connected.

In summary, research on student characteristics is disjointed and spotty, although that on moral development appears more coherent. Student attributes and achievement variables merit greater and more consistent study. Can we suppose anything about the outcomes of a university education if we do not understand the nature of our students?

\section{METHODS OF STUDENT SELECTION AND PREPARATION}

Some methods of student selection and preparation deserve attention. An investigation of different selection criteria for admission to an Ontario university showed that Grade 13 marks, SACU scores, teacher recommendations and personality test results correlated with final first year GPA standings (Pollock, Bowman, Gendreau \& Gendreau, 1975). Open admissions students who did not have satisfactory Grade 13 results performed in line with other goups. Results from the Tests of General Educational Development for non-high school graduates have been found to be good predictors of success in colleges and universities (Ayers, 1980). Nadeau (1977) found, however, that admissions criteria did not differentially affect graduation or perseverance in the education profession. This kind of result was also found by Toukmanian (1978): admission variables were essentially ineffective in predicting student teaching performance. The best single predictor of academic performance was the pre-education GPA. A biographical inventory was tested and shown to have predictive validity, particularly on the basis of the GPA criterion, but also of academic and practice teaching performance. In an attempt to determine whether selected personality and cognitive complexity scales could be used to predict the academic stability of university students, Corfield and Ogston (1973) compared the scores of over 1000 first-year university students with their progress through the first year. Students who remained in university tended to be somewhat more introverted and felt more comfortable in a structured situation than those who did not remain. Students who changed faculty appeared to feel more comfortable in unstructured situations than those who did not change. The studies on student selection criteria suggest the possibility of successful open admissions policies but also point out that grades are the best predictors of student success. The academic stability study and the findings on student activism and moral development paint a somewhat surprising picture of the university student personality. Is the typical university student an introverted, achievement-oriented individual operating with conventional moral reasoning?

Two upgrading programs appear to have been of benefit to selected groups of students, one in Newfoundland which followed students who needed some remedial help over five semesters (Sullivan \& Wilson, 1980), and the other a remedial tutoring and learning skills program which enabled Canadian Indians to achieve academic success (Walker, 1977). Where specific study skill sessions were integrated into the course work, students demons- 
trated performance superior to those who received tutoring or assistance on a haphazard basis. These studies suggest that given the opportunity, students can benefit from remedial and study skills programs in the university.

\section{UNIVERSITY ORGANIZATION AND OPERATION}

At the most global level of psychological contributions to higher education are staff development programs and psychological services. Staff development programs are often heavily oriented toward instructional development but their scope extends to professional and organizational development. Good (1975) points out the triangular relationship in the university between orientation to scholarship in the discipline, the institutional or societal demands, and student or teaching operations. He calls for procedures in the university that will allow careful choice to be made in academic management even though we operate according to a paradigm of disperse responsibility. In a study of the objectives and problems of staff development in Western Canadian colleges, Konrad (1973) found that in-service training, largely devoted to instructional improvement and professional development, were the major objectives, with orientation procedures and organizational development playing minor roles. The problems noted by respondents most frequently concerned the designing and availability of suitable programs, staff attitudes which are sometimes change-resistant and defensive, and fiscal and time constraints. Staff development programs have been slow to develop because they are not an institutional priority, but with the increasing need to rejuvenate an existing staff, more emphasis on staff development could be predicted. The Ontario Universities Program for instructional development was an example of the attempt to supply funds to facilitate staff development. Attempts to clarify the context of higher education and to make it more meaningful to faculty by dealing with faculty-based educational concerns appear to be a useful direction for faculty development.

Psychology has made specific contributions to the university community. Psychologists have traditionally been involved with remedial and clinical services in the university, but in an attempt at prevention, the psycho-social goals of one institution were studied and then psychologists took on facilitative "out-reach" roles within the university (Waxer \& White, 1973). The psychologists acted as consultants in the planning of the academic and social life of individual colleges within York University. The community psychology approach to the university was not only found to facilitate administrative policy-making but also proved valuable in introducing university students to a way of thinking about their living and working environment that they could carry out to the community at large (Waxer, 1974). Psychologists also provide us with models for university programs in their literature. Studies describing admissions criteria, goals and curriculum, and orientation and resources for programs have been documented for school psychology (Paananen \& Janzen, 1980), and for a graduate training program in the psychology of sensory deficits (Lambert \& West, 1979). The procedures and criteria of program planning could prove to be highly useful tools in the future.

\section{PROGRAM EVALUATION}

Program evaluation methods could also be expected to play a significant role in higher education in the near future. Between fiscal austerity and a demand for rational decision- 
making in publicly funded institutions, the role of program evaluation will undoubtedly increase in importance. The literature on program evaluation covers four aspects: the nature of evaluation; the evaluation of particular programs; the evaluation of research; and finally, the evaluation of university education itself. The necessity for recognizing values in evaluating and for attending to role relationships are two themes pursued by Toh (1976). He appraises the socio-politics of evaluation and suggests tactics for the greater utilization of evaluation results. Approaches to accountability are reviewed in the context of professional service delivery by Sinclair (1980). Her analysis of how to assure quality through the setting of standards could be usefully applied in institutions of higher education generally. Particular programs that have been reviewed include Quebec's Téléuniversité (Riverin-Simard \& Roberge-Brassard, 1977; Riverin-Simard, 1978), and postsecondary education in a prison (Duguid, 1980). The summarized evaluations of the Télé-université program provide both descriptive information about the population served and recommendations for the operation of such a program. The British Columbia penitentiary program is unique in its attempt to facilitate cognitive and moral development and to translate cognitive/moral growth into changed behavior. Both of these programs provide examples for innovative approaches to higher education.

Psychology serves as an example in another aspect of evaluation in higher education. In a series of articles on the quality of Canadian psychology departments, citation rates, journal publications, graduates placed on other staffs, educational level of the faculty, and staff size have been examined (Buss, 1976; Endler, 1977; Endler, 1979; Schaeffer \& Sulyma, 1979). Schaeffer and Sulyma were able to distinguish two groups of measures, one for "real quality," in terms of citations, graduates placed and educational level of faculty. This group of measures showed a high degree of internal consistency. The other group appeared to measure "visibility," indexed by publications, staff size, and percentage of Americans on stafff. The various methods were assessed in terms of their stability, face validity, objectivity, and corruptibility, with citations receiving the highest evaluation. Psychologists have also studied Canadian social psychology texts by citations analysis (Perlman, 1979). The methods used in these specific evaluations could prove useful in the assembly of program evaluation devices for higher education.

Evaluation of university education or experience has for the most part been spoken of in undertones. Although questions of the value of a university education have been raised generally in Canada as elsewhere, the issue has not been studied by Canadian psychologists except in two instances. An incisive survey of students' motives for attending university and satisfaction with the experience was completed by 14,000 students at Concordia University (Haccoun \& Breslaw, 1979). The researchers found that the greatest proportion of students $(44 \%)$ indicated that career preparation was the most important reason for attending university, although a sizeable proportion (34\%) considered intellectual development the most important reason. The criteria for evaluation of the university experience were quality of teaching, opportunity to meet others, quality of course content, general university atmosphere, intellectual quality of other students, course availability, and quality of administration. Older students, part-time students, and foreign students gave the university higher ratings than the majority group of young, Canadian full-time students did. Overall ratings showed that the university experience on the average was much as expected, with the greatest variance occurring in ratings of course availability, quality of administration, and university atmosphere. 
In a survey of attitudes of psychology students in six Canadian universities toward their university education, Yarmey (1974) found that students were more disposed to consider the purpose of the university to be the advancement of learning than as a base for obtaining wealth, power or other outcomes. Students tended to acknowledge that university experiences contribute to their quality of life, but were not certain that human usefulness is the prime criterion on which social support of university education should be based. They also agreed that the cost or economic benefit of university learning cannot be really measured. These studies suggest directions that could be taken to more fully understand the meaning of a university education and factors affecting the evaluation of the university. The literature on evaluation in the university provides hints rather than major directions. It would appear that program evaluation is as yet gastating, although some promising genes have been noticed.

\section{SIGNIFICANCE OF THE RESEARCH}

The actual or potential effect of research depends first on its quality and relevance to higher education, but as well on the ability of the higher education system to make use of it. Thus whether the research is appropriate or timely is a further criterion in judging the ultimate effect of the research. The greatest emphasis in the psychological literature is on cognition and learning. Research in these areas is significant for what it could do to improve the learning process in the university. Unfortunately it has to date had little impact because it operates counter to the prevailing university belief that learning, if at all a problem, is a problem for some students, and not for professors. We are still oriented more toward selection than toward the development of our students. It could be predicted, however, that universities will move to a position of greater concern about students' learning needs in the future. Some funding agencies, such as the Quebec Ministry of Education, are actively supporting research in this area. Pointedly, much needs to be done to provide not only a coherent body of knowledge, but even baseline descriptive information about learning processes in higher education. Most of the work with concrete and abstract learning has not been applied to knowledge as it is found in university programs. There are few opportunities taken in the university to study what learning actually occurs in a course or what background knowledge students bring to a course. Furthermore, because knowledge structures are peculiar not only to a discipline but to the individual professor, a great deal of careful, specific research must be done to provide answers to the core questions of what and how university students learn.

The evaluation of learning in the university is in an equally undeveloped state. Although grades and the effects of different kinds of evaluation have received some attention, the actual evaluation of learning has not been rationalized because learning goals and standards have not been set, except in a few accredited professional programs where this is a requirement. The university system appears particularly vulnerable here. If the work on knowledge structures in specific disciplines develops, however, it should provide a base for the evaluation of learning. And if this takes place and standards can be agreed upon, many of the problems of grading should be resolved. There is another significant question concerning the evaluation of learning and that is the purpose or use made of the evaluation. Most students have learned by the time they reach university that grades, the extrinsic rewards of learning, have greater importance or effect than the knowledge itself. We have seen that goals affect learning and that students prefer examinations which provide them 
with better learning opportunities. At the same time, university policy tends to deal with grading systems, which are summative, administrative procedures rather than formative and learning-oriented procedures. If learning is what universities are about, then the formative or instructive aspects of evaluation should have precedence.

Teaching is an area which is closer than learning is to the prevailing ethos in the university, although it has a secondary rank to research; and the bulk of the psychological research related to higher education has been done in this area. Most instructional research is related to methods, as could be expected since instruction is an applied process, and the research is more cohesive than in other terrains. The most potentially significant findings are those dealing with the characteristics of effective teaching or in teaching competencies. Knowing that Canadian university graduates appreciate mastery of subject matter, well prepared lectures and interest on the part of the professors is highly useful information in evaluating and improving teaching. The effect of different teaching methods on student learning is a relatively untouched but promising area for research. One topic of growing import has been spearheaded in faculties of education: innovative approaches to selfinstruction and the integration of theory and practice provide new perspectives on education as a lifelong occurrence and suggest the skills that need to be developed. The evaluation of teaching has had more written about it than any other area, with the research emphasis on the use of teacher rating forms. The knowledge that student ratings of teachers are highly reliable has great potential use. Convincing professors of the utility of student ratings of their teaching is not as easily done: it is not infrequent that psychological findings have a minimal socio-political impact. Universities do, however, appear to be moving toward measuring and rewarding excellence in teaching. Attention to a broader set of evaluation methods and to the developmental consequences of teaching evaluations are directions in which psychological research should be heading. Making teaching evaluation more useful to individual professors and to departments for instructional improvement and curriculum development is also a trend.

Research on student characteristics was culled from a variety of sources and shows minimal interrelation. The articles point rather to the expanse of research which could be done to tell us more about our students. If students complain of alienation it is not surprising given that we know so little about them. If we are responsible for the selection and guidance of our students, or alternatively, if admissions policies become more open, we need to know a geat deal more. The learned helplessness or learned incompetence research appears promising, and the research on moral behavior has social significance. But where in the university could a base could be found to provide for a more coherent and systematic study of the university population? Learning centers or student services come to mind as potential sites, but would research of this kind be a sufficiently high priority for the administration of a university to devote resources to it? The studies on methods of student selection and preparation give hope that some attention is being paid to the students themselves and how to accommodate them in the university.

Psychological contributions to the organization and operation of the university are specific rather than global. Staff development has been supported to some extent in Canadian universities and could be expected to increase as the professoriate stabilizes. The innovative use of psychologists as consultants in the planning of the academic and social life of one university provides an example of a significant practical contribution of psychology to higher education.

Program evaluation is a major area of needed research. It is critical to the survival and 
adaptation of higher education. The universities have been slow to adopt the values of accountability and information-based decision-making that underlie the process of program evaluation, perhaps because in the university these values are considered to be inherent rather than open steps to be taken, or because a university considers itself to be the final arbiter rather than a social organization which must display good government. How to do program evaluation has received little attention to date, although certain institutions like the University of Alberta have instituted a program evaluation system and more are recognizing the demand for it. The delineation of important criteria for evaluation in higher education is not yet in print, nor are equitable and just procedures. Certainly this would be a contribution of major significance that is yet to be made.

Overall, the review of psychological contributions to higher education in Canada gives us a set of factors which could affect higher education rather than a set of effects. We have some knowledge in the areas of cognition and learning and in the evaluation of learning, but much more to do to make it applicable in the university or college setting. The area of instruction is better studied, and could be fruitfully disseminated. Student characteristics are virtually undocumented in the literature in any systematic fashion, though the research suggests a variety of factors which merit study. Research on the organization of institutions and on program evaluation provides hints of steps to be taken. All of the research reported shows potential significance, but the degree of impact is questionable, except in particular cases where psychologists have acted as academic planning consultants. The greatest gaps occur in the ordered or systematic pursuit of a defined research area: the work on student ratings of teaching is an exception to this.

To answer the questions, "What should be done?" and "What could be done?", groundwork is first needed to provide a setting for organized and continued study of higher education. Three areas of research merit particular support. The first would be centered on the problems of student learning and the nature of learning and knowledge. Cognitive organization would be a key topic of research. The second would be oriented to the fuller development of faculty and students within the context of a learning community. An analysis of student characteristics and their effects on learning would be of particular importance. The third area would be the organization of the university, with special emphasis upon how decisions are made and what criteria and information are used in making them. The university is founded on the axiom of rationality and ought to be able to operate accordingly, without damage to academic freedom and with far greater socio-political strength as a result. In an era of constraints and questioning, the university needs to know itself.

\section{REFERENCES}

Abrami, P.C., Dickens, W.J., Perry, R.P., \& Leventhal, L. Do teacher standards for assigning grades affect student evaluations of instruction? Journal of Educational Psychology, 1980, 72, 107-117.

Allard, G.Y. Une expérience de formation pratique des futurs-maîtres centrée sur l'auto-formation. Canadian Journal of Education, 1977, 2 (2), 33-44.

Allen, D.J. Extending the practicum: problems in integrating theory and practice. Canadian Journal of Education, 1976,1 (3), 43-51.

Ayers, J.D. Relationship of first-year university grades of non-high school graduates with the Tests of General Educational Development. Canadian Journal of Higher Education, 1980, 10 (1), 75-82. 
Bavelas, J., \& Lee, E.S. Effects of goal level on performance: a trade-off of quantity and quality. Canadian Journal of Psychology, 1978, 32 (4), 219-240.

Bellerose, J., Bégin, G., Frenette, C., \& de Montigny, C. La technique de la réponse aléatoire: un moyen facile de juger l'authenticité des auto-enregistrements des sujets. Canadian Journal of Behavioral Science, 1980, 12 (1), 98-103.

Berg, K.S., \& Stone, G.L. Modelling and instructional effects as a function of conceptual level. Canadian Journal of Behavioral Science, 1978, 10 (2), 152-161.

Buss, A.R. Evaluation of Canadian psychology departments based upon citation and publication counts. Canadian Psychological Review, 1976, 17 (2), 143-150.

Cantin, G., \& Chené-Williams, A. L'intégration des apprentissages: du pourquoi au comment. Revue des sciences de l'éducation, 1978, 4 (3), 375-387.

Carr, R.A. The effects of specific guidelines on the accuracy of student self-evaluation. Canadian Journal of Education, 1977, 2 (4), 65-77.

Castonguay-Leblanc, Y. L'enseignement personnalisé au collège et à l'université. Canadian Journal of Education, 1977, 2 (4), 37-54.

Clifton, R.A., \& Baksh, I.J. Physical attractiveness, year of university, and the expectations of studentteachers. Canadian Journal of Education, 1978, 3 (3), 37-46.

Clifton, R.A. \& Covert, J. The effects of an experimental program on the motivation and self-concept of student teachers. Canadian Journal of Education, 1977, 2 (2), 23-32.

Cochran, L. Categorization and change in conceptual relatedness. Canadian Journal of Behavioral Science, 1976, 8 (3), 275-286.

Connolly, J., \& McCarrey, M. The relationship between levels of moral judgment maturity and locus of control. Canadian Journal of Behavioral Science, 1978, 10 (2), 162-175.

Corfield, V.K., \& Ogston, D.G. Personality correlates of academic stability among university freshmen. The Canadian Psychologist, 1973, 14 (3), 281-289.

Cranton, P.A. The McGill faculty and course evaluation system. Canadian Joumal of Higher Education, 1979,9 (1), 11-16.

Das, H., Frost, P.J., \& Barnowe, J.T. Behaviorally anchored scales for assessing behavioral science teaching. Canadian Journal of Behavioral Science, 1979, 11 (1), 79-88.

Davey, E.B. Select bibliography of evaluation of instruction in higher education. Canadian Journal of Higher Education, 1979, 9 (1), 65-72.

Demers, M. La didactique des sciences par contrat. Canadian Journal of Education, 1978, 3 (2), 27-41.

Donald, J.G. Modular instruction: a resource book. Montreal: McGill University, Centre for Learning and Development, 1977.

Donald, J.G. Where to begin? Priorities for teaching improvement. Proceedings, Fourth International Conference on Improving University Teaching, Aachen, Germany, 1978, 4, 1257-1267.

Donald, J.G. Structures of knowledge and implications for teaching. Centre for the Improvement of Teaching, University of British Columbia, Report No. 6, 1980. (ERIC Document ED 189921.)

Donald, J.G., \& Shore, B.M. Annotated index to pedagogical services in Canadian universities and colleges. Montreal: Centre for Learning and Development, McGill University, 1976.

Dowdeswell, W.H., \& Good, H.M. Course evaluation for academic management - a case study in biology. Canadian Journal of Higher Education, 1979, 9 (1), 23-44.

Duguid, S. Post-secondary education in a prison: theory and praxis. Canadian Journal of Higher Education, 1980, 10 (1), 29-35.

Emerson, G.J. Factors related to enlarged perspectives among the students of an Ontario Teachers' College. Canadian Journal of Education, 1977, 2 (2), 45-63.

Endler, N.S. Research productivity and scholarly impact of Canadian psychology departments. Canadian Psychological Review, 1977, 18(2), 152-168.

Endler, M. Where the "stars" are: the 25 most cited psychologists in Canada (1972-1976). Canadian Psychological Review, 1979, 20 (1), 12-21.

Ernest, C.H., \& Paivio, A. Imagery and verbal assaciative latencies as a function of imagery ability. Canadian Journal of Psychology, 1971, 25 (1), 83-90. 
Foster, S.F., \& Nelson, J.G. Teaching improvement in Canada: data concerning what and how. Canadian Journal of Higher Education, 1980, 10 (2), 120-125.

Foth, D.L. Evaluative devices as learning opportunities. Canadian Joumal of Higher Education, 1975, $5(1), 65-72$.

Furedy, C. Improving lecturing in higher education. Canadian Journal of Higher Education, 1979, $9(1), 45-54$.

Furedy, J. J., \& Furedy, C. Modelling the realities of research experience: collaboration against common and merciless foes. Canadian Journal of Higher Education, 1978, 8 (1), 79-87.

Gagné, F., D’Ivernois, J.-F., Parent, J., \& Marquis, Y. Perceptions étudiantes comparées de deux formes d'enseignement programmé. Revue des sciences de l'éducation, 1976, 2 (1), 3-11.

Geis, G.L. Evaluation: purposes and levels. Canadian Journal of Higher Education, 1979, 9 (1), 1-4.

Gingras, J.-M. La notion d'objectif pédagogique dans le domaine affectif et son utilité dans l'enseignement du français au collégial. Revue des sciences de l'éducation, 1975, 1 (2) (3), 113-127.

Goldschmid, B., \& Goldschmid, M.I. Modular instruction in higher education: a review. Montreal: McGill University, Centre for Learning and Development, 1972.

Good, H.M. Instructional development - What? Why? How? Canadian Journal of Higher Education, 1975,5 (1), 33-51.

Green, G., \& Cochran, L. Meaningfulness of categorization and influence upon impression formation. Canadian Journal of Behavioral Science, 1978, 10 (4), 339-350.

Gregory, A., \& Allen, D.I. Some effects of the practicum on the professional self-concept of student teachers. Canadian Journal of Education, 1978, 3 (2), 53-65.

Haccoun, D.M., \& Breslaw, J. The evaluation of university experience: an examination of motives and satisfaction. Canadian Journal of Behavioral Science, 1979, 11 (3), 205-213.

Hartsough, W.R. Illusory correlation and mediated association: a finding. Canadian Journal of Behavioral Science, 1975, 7 (2), 151-154.

Henderson, J., Briere, J., \& Hartsough, R. Sexism and sex roles in letters of recommendation to graduate training in psychology. Canadian Psychology, 1980, 21 (2), 75-80.

Humphreys, M.S., \& Yuille, J.C. Errors as a function of noun concreteness. Canadian Journal of Psychology, 1973, 27 (1), 83-94.

Knapper, C. The impact of research on college teaching: a Canadian case study. Paper presented at the annual meeting of the American Psychological Association, Montreal, 1980.

Knapper, C.K., et al. If teaching is important. . the evaluation of instruction in higher education. Canadian Association of University Teachers; Clarke-Irwin, 1977.

Kolers, P.A. Two kinds of recognition. Canadian Journal of Psychology, 1974, 28 (1), 51-61.

Konrad, A.G. Staff development in Western Canadian colleges. STOA, 1973, 3 (1), 47-52.

Lamarche, L. L'intégration de l'information en fonction de la polysémie des stimuli. Canadian Journal of Behavioral Science, 1977, 9 (3), 233-241.

Lambert, R.M., \& West, M.L. North America's first graduate training program in the psychology of sensory deficits. Canadian Psychological Review, 1979, 20 (4), 184-188.

Leibu, Y. La qualité de l'enseignement universitaire: essai d'approche systématique. Canadian Journal of Higher Education, 1976, 6 (3), 1-11.

Lerclerc, C., \& Freibergs, V. L'influence d'indices subliminaux, perceptifs et symboliques sur la formation d'un concept. Canadian Journal of Psychology, 1971, 25 (4), 292-301.

Leven thal, L. Teacher rating forms: critique and reformulation of previous validation designs. Canadian Psychological Review, 1975, 16 (4), 269-276.

Leventhal, L. The Doctor Fox effect: an alternative interpretation. Instructional Evaluation, 1979 , 4 (1), 1-6.

Leventhal, L., Abrami, P.C., \& Perry, R.P. Do teacher rating forms reveal as much about students as about teachers? Journal of Educational Psychology, 1976, 68, 441-445.

Magsino, R.F. Competencies for teaching: confronting the real priority in Canadian education. Canadian Journal of Education, 1979,4 (4), 66-80. 
Martin, J., Marx, R.W., Hasell, J., \& Ellis, J.F. Improving the instructional effectiveness of university teaching assistants. Report II. Canadian Journal of Education, 1978, 3 (2), 13-26.

Marx, R.W., Ellis, J.F., \& Martin, J. The training of teaching assistants in Canadian universities: a survey and case study. Canadian Journal of Higher Education, 1979, 9 (1), 55-63.

Marx, R.W., Martin, J., Ellis, J.F., \& Hasell, J. Improving the instructional effectiveness of university teaching assistants: Report I. Canadian Journal of Education, 1978, 3 (2), 1-12.

Mason, G.P. Adjusting the nominal maximum for tests of unknown difficulty. Canadian Journal of Higher Education, 1978, 8 (1), 101-105.

Morin, L. Considérations sur les fins de l'enseignement universitaire. Revue des sciences de l'éducation, 1976,2 (3), 157-175.

Morse, S.J. Being a Canadian: aspects of national identity among a sample of university students in Saskatchewan. Canadian Journal of Behavioral Science, 1977, 9 (3), 265-273.

Murray, H.G. The validity of student ratings of faculty teaching ability. Paper presented at the meeting of the Canadian Psychological Association, Montreal, 1972.

Murray, H.G. Evaluating university teaching: a review of research. Toronto: Ontario Confederation of University Faculty Associations, 1979.

Nadeau, G.G. Validité prédictive de certaines variables d'admission dans un collège d'éducation. Revue des sciences de l'éducation, 1977,3 (1),67-94.

O'Neill, B.J., \& Paivio, A. Some consequences of violating selection restrictions in concrete and abstract sentences. Canadian Journal of Psychology, 1978, 32 (1), 3-18.

Paananen, N., \& Janzen, H.L. Survey of Canadian school psychology training programs. Canadian Psychology, 1980, 2 (1), 14-16.

Parent, J. Le rôle d'un service de pédagogie universitaire dans l'évaluation de cours. Canadian Journal of Higher Education, 1979,9 (1), 5-9.

Pascal, C.E., \& Davey, E.B. The politics of evaluating teaching. Canadian Journal of Higher Education, $1979,9(1), 17-21$.

Pedersen, P. A note on current teaching and research in the psychology of music in Canada. Canadian Psychological Review, 1977, 18 (3), 264-267.

Percival, T.Q. Cognitive and motivational parallels in moral development. Canadian Joumal of Behavioral Science, 1979, 11 (3), 214-224.

Perlman, D. Eight social psychology texts: a citations analysis. Canadian Psychological Review, 1979, $20(1), 38-47$.

Perry, R.P., Leventhal, L., Abrami, P.C., \& Dickens, W. Learned helplessness in the college classroom: are teacher characteristics involved? Paper presented at the meeting of the American Psychological Association, Toronto, 1978.

Perry, R.P., Abrami, P.C., \& Leventhal, L. Educational seduction: the effect of instructor expressiveness and lecture content on student ratings and achievement. Journal of Educational Psychology, $1979,79,107-116$.

Pollock, G., Bowman, R.J., Gendreau, P., \& Gendreau, L. An investigation of selection criteria for admission to an Ontario university. Canadian Journal of Higher Education, 1975, 5 (3), 1-16.

Quarter, J. Political socialization at the University of Toronto: a three-year longitudinal study. Canadian Journal of Behavioral Science, 1974, 6 (3), 219-233.

Rayko, D.S. Does knowledge matter? Psychological information and bystander helping. Canadian Journal of Behavioral Science, 1977, 9 (4), 295-304.

Reich, C.M. The generalization of assertions throughout a cognitive network. Canadian Journal of Psychology, 1974, 28 (3), 288-299.

Riverin-Simard, D. L'évaluation éducationnelle à la télé-université. Canadian Joumal of Higher Education, 1978, 8(2), 9-25.

Riverin-Simard, D. Entraînement à la flexibilité par l'apprentissage observationnel abstrait. Revue des sciences de l'éducation, 1977, 3 (2), 135-159.

Riverin-Simard, D., \& Roberge-Brassard, J. Synthèse des travaux de recherche sur la télé-université. Revue des sciences de l'éducation, 1977, 3 (3), 279-301. 
Runquist, W.N., \& Blackmore, M. Phonemic storage of concrete and abstract words with auditory presentation. Canadian Journal of Psychology, 1973, 27 (4), 456-463.

Sadava, S.W. A field-theoretical study of college student drug use. Canadian Journal of Behavioral Science, 1971,3 (4), 337-346.

Sadava, S.W. Initiation to cannabis use: a longitudinal social psychological study of college freshmen. Canadian Journal of Behavioral Science, 1973, 5 (4), 371-384.

Sadava, S.W. Teaching social psychology: a Canadian dilemma. Canadian Psychological Review, 1978, $19(2), 145-151$.

Sandilands, M.L. The effect of conceptual structure and commitment on exposure to discrepant information. Canadian Journal of Behavioral Science, 1974, 6 (4), 318-331.

Schaeffer, D.L., \& Sulyma, I.M. Citation rates and the quality of Canadian psychology departments. Canadian Psychological Review, 1979, 20 (1), 22-37.

Segalowitz, N. Communicative incompetence and the non-fluent bilingual. Canadian Journal of Behavioral Science, 1976, 8 (2), 122-131.

Sergent, J., \& Lambert, W.E. "Learned helplessness" or "learned incompetence"? Canadian Journal of Behavioral Science, 1979, 11 (4), 257-273.

Sheffield, E.F. Characteristics of effective teaching in Canadian universities - an analysis based on the testimony of a thousand graduates. Canadian Journal of Higher Education, 1974, 4 (1), 7-29.

Shore, B.M. Strategies for the implementation of modular instruction and their implications for university education. The Journal of Higher Education, 1973, 44, 680-697.

Sinclair, C. Standards as a vehicle of accountability. Canadian Psychology, 1980, 21 (1), 1-6.

Sullivan, A.M. Psychology and teaching. Canadian Journal of Behavioral Science, 1974, 6 (1), 1-29.

Sullivan, A.M. Research on teaching. Canadian Journal of Higher Education, 1975, 5 (1), 1-11.

Sullivan, A.M., \& Wilson, P. A successful academic upgrading programme follow-up over five semesters. Canadian Journal of Higher Education, 1980, 10 (2), 85-101.

Taylor, I.A., \& Fish, T.A. The Creative Behavior Disposition Scale: a Canadian validation. Canadian Journal of Behavioral Science, 1979, 11 (1), 95-97.

Taylor, H. Differences in grading systems among Canadian universities. Canadian Journal of Higher Education, 1977, 7 (1), 47-54.

Taylor, I. How are words from two languages organized in bilinguals' memory? Canadian Journal of Psychology, 1971, 25 (3), 228-240.

Thompson, A.P., Reberg, B.J., \& Uhlemann, M.R. Canadian normative data for the McGraw-Hill Study Skills Test from a Canadian university. Canadian Journal of Behavioral Science, 1978, 10 (3), 267-269.

Toh, S.H. The socio-politics of evaluating: some issues of values, roles, and tactics. Canadian Journal of Education, 1976, 1 (2), 63-74.

Toukmanian, S. The biographical inventory approach to the selection of teacher trainees. Canadian Journal of Education, 1978, 3 (3), 11-19.

Traub, R.E., \& Hambleton, R.K. The effect of instruction on the cognitive structure of statistical and psychometric concepts. Canadian Journal of Behavioral Science, 1974, 6 (1), 30-44.

Trow, M. The public and private lives of higher education. Daedalus, 1975, 2, 113-127.

Vernon, P.E., Ryba, K.A., \& Lang, R.J. Simultaneous and successive processing: an attempt at replication. Canadian Journal of Behavioral Science, 1978, 10 (1), 1-15.

Walker, L.S. University success for Canadian Indians. Canadian Journal of Behavioral Science, 1977 , $9(2), 169-175$.

Ware, E.E., Brown, M., Amoroso, D.M., Pilkey, D.W., \& Pruesse, M. The semantic meaning of pornographic stimuli for college males. Canadian Journal of Behavioral Science, 1972, 4 (3) , 204-209.

Waxer, P. Community psychology in colleges II: psychologist as administrator. The Canadian Psychologist, $1974,15(3), 251-257$. 
Waxer, P., \& White, R. In troducing psychological consultation to a university community. The Canadian Psychologist, 1973, 14 (3), 256-265.

Yarmey, A.D., \& Barker, W.J. Repetition vs. imagery instructions in the immediate-and delayedretention of picture and word paired-associates. Canadian Journal of Psychology, 1971, 25 (1), 56-61.

Yarmey, A.D. Appreciation of university education in relation to employment expectations. The Canadian Psychologist, 1974, 15 (2), 165-177.

Yarmey, A.D., \& Sayer, L.A. Associative learning of abstract and concrete nouns and their subject drawn pictorial representations. Canadian Journal of Psychology, 1972, 26 (3), 240-251.

Yuille, J.C., \& Holyoak, K. Verb imagery and noun phrase concreteness in the recognition and recall of sentences. Canadian Journal of Psychology, 1974, 28 (3), 359-370.

Zemore, R., \& Johansen, L.J. Depression, helplessness, and failure attributions. Canadian Journal of Behavioral Science, 1980,12 (2), 167-174. 